\title{
New-particle formation events in a continental boundary layer: first results from the SATURN experiment
}

\author{
F. Stratmann ${ }^{1}$, H. Siebert ${ }^{1}$, G. Spindler ${ }^{1}$, B. Wehner $^{1}$, D. Althausen ${ }^{1}$, J. Heintzenberg ${ }^{1}$, O. Hellmuth ${ }^{1}$, R. Rinke ${ }^{1}$, \\ U. Schmieder $^{1}$, C. Seidel ${ }^{1}$, T. Tuch ${ }^{1}$, U. Uhrner ${ }^{1}$, A. Wiedensohler ${ }^{1}$, U. Wandinger ${ }^{1}$, M. Wendisch ${ }^{1}$, D. Schell ${ }^{2}$, and \\ A. Stohl ${ }^{3}$ \\ ${ }^{1}$ Institute for Tropospheric Research, Leipzig, Germany \\ ${ }^{2}$ enviscope GmbH, Frankfurt/Main, Germany \\ ${ }^{3}$ Technical University of Munich, Freising, Germany
}

Received: 6 February 2003 - Published in Atmos. Chem. Phys. Discuss.: 27 March 2003

Revised: 10 September 2003 - Accepted: 11 September 2003 - Published: 22 September 2003

\begin{abstract}
During the SATURN experiment, which took place from 27 May to 14 June 2002, new particle formation in the continental boundary layer was investigated. Simultaneous ground-based and tethered-balloon-borne measurements were performed, including meteorological parameters, particle number concentrations and size distributions, gaseous precursor concentrations and SODAR and LIDAR observations.

Newly formed particles were observed inside the residual layer, before the break-up process of the nocturnal inversion, and inside the mixing layer throughout the break-up of the nocturnal inversion and during the evolution of the planetary boundary layer.
\end{abstract}

\section{Introduction}

Atmospheric aerosol particles influence climate (e.g., Charlson and Heintzenberg, 1995) and human health (e.g., Dockery and Pope, 1994). An important source of atmospheric aerosols is new particle formation from gaseous precursors, i.e., homogeneous nucleation. If newly formed particles grow up to diameters of about $50 \mathrm{~nm}$ and larger they become climatically relevant as particles in this size range can act as cloud condensation nuclei $(\mathrm{CCN})$. A changing number of $\mathrm{CCN}$ may affect the size of cloud droplets and consequently the radiative properties of clouds. This effect is called the indirect aerosol effect on climate. If the newly formed particles grow up to sizes above $100 \mathrm{~nm}$, they start to scatter light efficiently and alter the radiative properties of the Earth's atmosphere directly. This effect is called the direct effect of aerosol particles on climate.

Correspondence to: F. Stratmann

(straddi@tropos.de)
Nucleation, usually detected as enhanced number concentration of particles in the size range below $10 \mathrm{~nm}$, has been observed in Arctic areas (Wiedensohler et al., 1996; Pirjola et al., 1998), in marine locations (e.g., Hoppel et al., 1994; O'Dowd et al., 1999) and in continental locations, such as boreal forests (Mäkelä et al., 1997; Nilsson et al., 2001), remote (e.g., Weber et al., 1997), polluted sites (e.g., Birmili and Wiedensohler, 2000; McMurry et al., 2000), the free troposphere (Clarke, 1992; Schröder and Ström, 1997), and in the vicinity of evaporating clouds (Hegg et al., 1990; Wiedensohler et al., 1997; Keil and Wendisch, 2001).

To date, the fundamental processes causing nucleation and subsequent growth into the size-range of a few nanometers are still not well understood. Most likely there is not only one mechanism that controls atmospheric nucleation processes. Weber et al. (1999) e.g., suggested that nucleation mechanisms may vary with altitude. Other researchers noted that favourable atmospheric conditions, such as turbulence due to breaking Kelvin-Helmholtz waves (Bigg, 1997) or boundary layer mixing processes (Easter and Peters, 1994; Nilsson and Kulmala, 1998; Hellmuth and Helmert, 2002; Uhrner et al., 2002), and atmospheric waves in general (Nilsson et al., 2000) can enhance nucleation rates by up to several orders of magnitude. However, most of the measurements reported in the literature are single point measurements and therefore not suitable to gain insight into the above mechanisms.

Consequently, since the first long-term ground-based nucleation observations reported (Mäkelä et al., 1997), the question whether the observed newly formed particles nucleated near the ground or were mixed down from above, is still unanswered. To gain further insight into this problem, i.e., to determine possible loactions where new particle formation may take place, the SATURN ("Strahlung, vertikaler Austausch, Turbulenz und Partikel-Neubildung", radiation, vertical exchange, turbulence and new particle formation) 


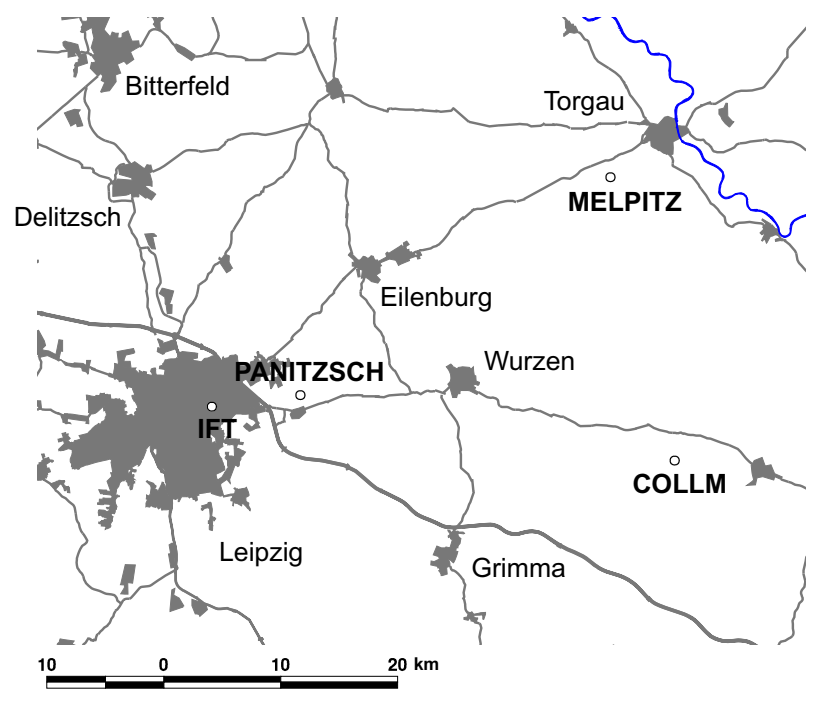

Fig. 1. Map of the measurement sites during SATURN.

experiment was carried out. In this work first results from the SATURN experiment are reported. Instead of performing only single point measurements, vertical soundings of meteorological parameters such as wind, temperature, relative humidity, and particle number concentrations were carried out utilizing a unique balloon-borne measurement platform. In addition, ground-based measurements of particle number size distributions and gaseous precursor concentrations $\left(\mathrm{SO}_{2}, \mathrm{NH}_{3}\right)$ were performed at the site where the balloon was launched. Furthermore, at two additional locations (distance to the balloon site is about $40 \mathrm{~km}$ ) particle number size distributions were measured. To gain information about the vertical structure and the development of the boundary layer, SODAR measurements were performed at the balloon site and a LIDAR was operated at about $50 \mathrm{~km}$ apart from the balloon site.

\section{SATURN Experiment}

\subsection{Experimental sites}

During the SATURN experiment, which took place from 27 May to 14 June 2002, measurements were taken at three measurement sites (Fig. 1), i.e., Melpitz, Collm, and Panitzsch. All three sites can be classified as rural, urban influenced with varying distances to the city of Leipzig. Additionally, LIDAR measurements were performed at the Institute for Tropospheric Research (IfT) in Leipzig.

Melpitz: The Melpitz site (51.526 N, 12.928 E, $87 \mathrm{~m}$ asl), located about $42 \mathrm{~km}$ north-east of Leipzig, is the permanent research station of the IfT and is situated near the village Melpitz in the vicinity of the city of Torgau (river Elbe valley). The station is located on a flat meadow (approximately $400 \mathrm{~m} \times 500 \mathrm{~m}$ ) surrounded by agricultural land. The near- est road is passing by around $1.5 \mathrm{~km}$ to the north. Edges of forests are $2.5 \mathrm{~km}$ to the north (Dübener Heide) and $1 \mathrm{~km}$ to the south (Dahlener Heide). For further information see Spindler et al. (1996) and Spindler et al. (2001).

Collm: The measurement site Collm is located on the isolated hill Collm (51.3077 N, 13.0026 E, $230 \mathrm{~m}$ asl) approximately $40 \mathrm{~km}$ south-east of Leipzig. It is surrounded by small villages, forests, and agriculturally used areas and features a busy national road approximately $2 \mathrm{~km}$ from the measurement site. The hill is mainly covered with forest. The building of Collm Observatory of the Leipzig University hosted the measurement. Instrumentation was set up on the highest floor of the building and the aerosol inlet was mounted $1 \mathrm{~m}$ above the building, corresponding to a height of $25 \mathrm{~m}$ above ground.

Panitzsch: The site in the village Panitzsch $(51.361 \mathrm{~N}$, $12.544 \mathrm{E}, 139 \mathrm{~m}$ asl, approximately $10 \mathrm{~km}$ to the east of Leipzig) was located at the edge of a residential area. The measurement van was set up $5 \mathrm{~m}$ from a local road and approximately $20 \mathrm{~m}$ from a wheat field to the east. The surrounding area is flat and open to the east and north. The aerosol inlet was mounted on a $10-\mathrm{m}$ mast. The height of the nearby housing was approximately $1 \mathrm{~m}$ below the inlet height.

\subsection{Balloon-borne measurements of turbulence, trace gas, and particle number concentration in Melpitz}

To measure the vertical distribution of particle number concentrations and turbulence (wind vector, temperature, and humidity) the tethered-balloon-borne payload ACTOS (Airship-borne Cloud Turbulence Observation System) was used. This system was originally developed to measure turbulence and microphysical parameters in boundary-layer clouds (Siebert et al., 2003a). For the SATURN-experiment ACTOS was equipped with the following instruments.

- An ultrasonic ("sonic") anemometer/thermometer (Solent HS, Gill Instruments Ltd., Lymington, United Kingdom) was used to measure the three-dimensional wind vector with $100-\mathrm{Hz}$ resolution (Siebert and Muschinski, 2001). To correct the measured wind vector for attitude and lateral motion a navigation unit including GPS (Global Positioning System) and inertial sensors was included. The measurement height was derived from the static pressure measured with a barometer (PTB220, Vaisala Oy, Helsinki, Finland) and from GPS. The humidity fluctuations were determined with a closed Lyman- $\alpha$ absorption hygrometer which was calibrated against a slow but more accurate capacitive sensor (Humicap HMP232, Vaisala Oy, Helsinki, Finland). The temperature fluctuations were measured with fine-wire sensors (UFT-B, see Haman et al., 2000), additionally the virtual temperature was derived from the speed of sound as measured with the sonic. Both probes were calibrated with an airborne thermometer 


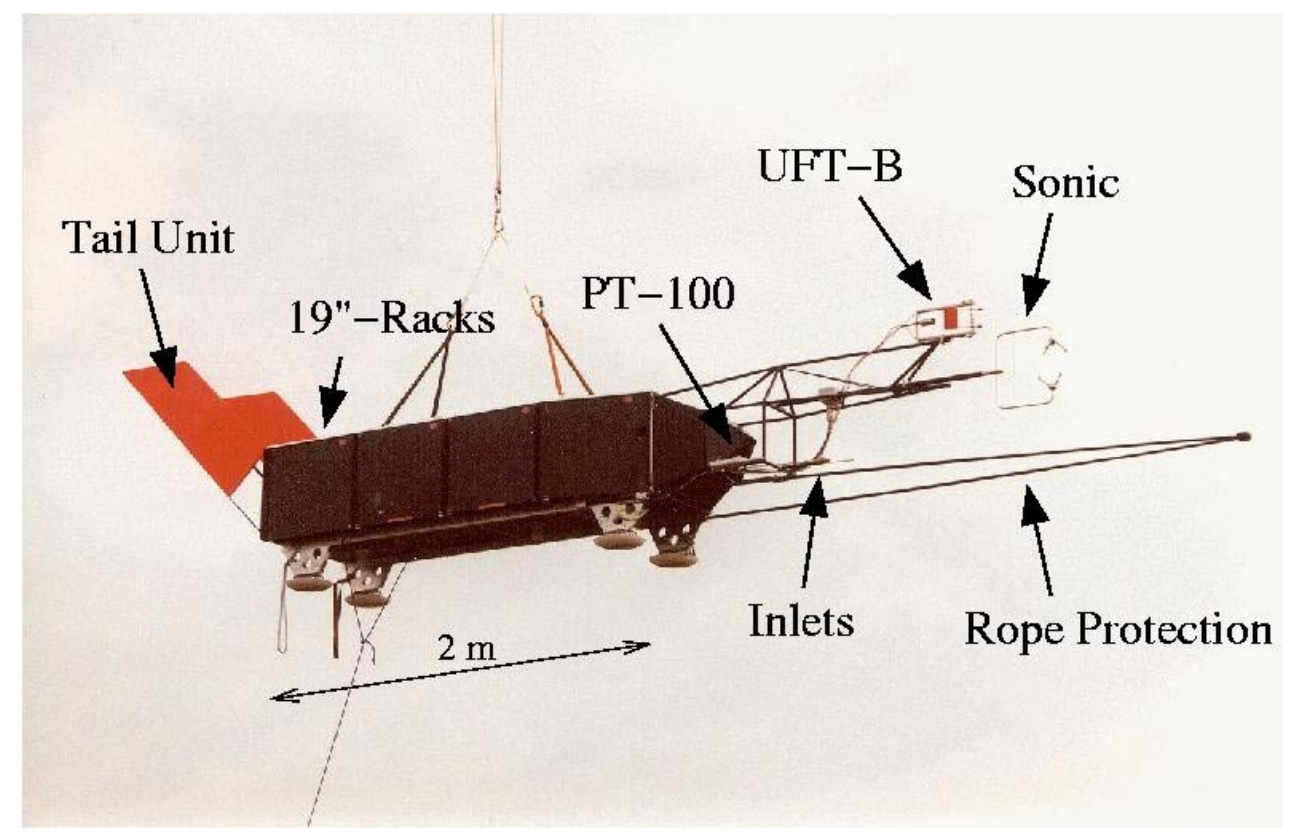

Fig. 2. The tethered-balloon borne payload ACTOS with ultrasonic anemometer (sonic), ultra-fast thermometer (UFT-B), and inlet for particle measurements.

(PT-100, T-139, Rosemount Inc., Eagan, MN, USA). A real-time data acquisition system with telemetry link for ground monitoring completes the standard equipment of ACTOS.

- Two condensation particle counters (CPCs, model 3762, TSI Inc., St. Paul, MN, USA) were run in parallel for particle number concentration measurements. Both CPCs were operated at a flow rate of $1.51 \mathrm{~min}^{-1}$ but at different temperature differences $\Delta T$ between saturator and condenser (CPC-I $\Delta T=18 \mathrm{~K}$ and CPC-II $\Delta T=24 \mathrm{~K}$ ). Banse et al. (2001) determined the lower cut-off sizes of the TSI- 3762 at $20 \mathrm{~K}$ and $23 \mathrm{~K}$ to 8 and $5 \mathrm{~nm}$. For $\Delta T=18$ and $24 \mathrm{~K}$, the lower cut-off size can be estimated to about 10 and $5 \mathrm{~nm}$, respectively. From the two number concentrations $N_{I}$ and $N_{I I}$ measured with these CPCs, the number concentration $\Delta N$ of particles in the diameter range 5-10 nm was determined. The time resolution of the concentration measurements is in the order of one second (Buzorius et al., 1998).

- For the detection of $\mathrm{SO}_{2}$ gas-phase concentrations a THERMO ENVIRONMENTAL, Model 43C Trace Level Instrument with a time resolution of $10 \mathrm{~s}$ was used. Since this instrument is designed for groundbased operation, it was modified with respect to weight reduction and power supply. Zero-point stabilization and span of the signal have been checked each day in the field by using an activated carbon filter bag and a 20 ppb standard-gas Teflon bag, respectively.
The complete system ACTOS is about $4 \mathrm{~m}$ in length and the payload is about $110 \mathrm{~kg}$. The setup is illustrated in Fig. 2 with indication of the main sensor equipment. ACTOS together with the tethered balloon MAPS-Y is shown in Fig. 3. The ceiling of the system is at about $1.3 \mathrm{~km}$ at maximum wind speeds of 10-15 $\mathrm{m} \mathrm{s}^{-1}$. A more detailed description of the turbulence sensors and a general introduction of ACTOS and MAPS-Y is given by Siebert (2001) and Siebert et al. (2003a).

Table 1 gives an overview of all balloon soundings during the SATURN experiment with an estimation of the maximum values of $\Delta N$ observed in the mixing layer (ML) and the residual layer $(\mathrm{RL})$.

\subsection{Measurements of meteorological parameters and trace-} gas concentrations at the Melpitz site

At the Melpitz site continuous measurements of meteorological parameters and trace gas concentrations were carried out during the SATURN experiment. Global solar radiation was measured using a pyranometer (CM11, Kipp \& Zonen, Germany). Dry and wet bulb temperatures (PT100) were determined utilizing a psychrometer (Thies, Germany). In combination with pressure measurements (Vaisala, Germany), the relative humidity was calculated. Measurements of wind direction and horizontal wind velocity were carried out using a wind vane (Siggelkow, Germany) and a cup anemometer (Siggelkow, Germany), respectively. The temperature was measured $2.4 \mathrm{~m}$ above ground, wind direction and horizontal wind velocity at $12 \mathrm{~m}$ and $11.7 \mathrm{~m}$ height, respectively. 
Table 1. Overview of all observations with the tethered balloon system ACTOS/MAPS-Y including date and start time of the soundings. An estimation of the maximum value of $\Delta N$ is given for the ML and RL. A " $/$ " denotes, that this region was not clearly observed or could not reached with the balloon at this time.

\begin{tabular}{|c|c|c|c|c|}
\hline No. & Date & Time [UTC] & $\Delta N_{\max }$ in $\mathrm{ML}$ & $\Delta N_{\max }$ in $\mathrm{RL}$ \\
\hline 1 & $02-05-29$ & $09: 46$ & 1600 & I \\
\hline 2 & $02-05-30$ & $06: 20$ & 0 & 0 \\
\hline 3 & $02-05-30$ & $07: 15$ & 300 & 0 \\
\hline 4 & $02-05-30$ & $08: 28$ & 100 & I \\
\hline 5 & $02-05-30$ & 08:41 & 300 & I \\
\hline 6 & 02-06-01 & 04:10 & 0 & 0 \\
\hline 7 & 02-06-01 & $04: 21$ & 0 & 0 \\
\hline 8 & $02-06-01$ & $05: 31$ & 0 & 0 \\
\hline 9 & $02-06-01$ & $05: 43$ & 50 & 0 \\
\hline 10 & 02-06-01 & 07:03 & 0 & I \\
\hline 11 & 02-06-01 & $08: 45$ & 100 & I \\
\hline 12 & 02-06-02 & 03:50 & 0 & 0 \\
\hline 13 & $02-06-02$ & $06: 16$ & 300 & 0 \\
\hline 14 & $02-06-02$ & $06: 30$ & 500 & 0 \\
\hline 15 & $02-06-02$ & 09:00 & 100 & 50 \\
\hline 16 & $02-06-02$ & 09:30 & 150 & 100 \\
\hline 17 & $02-06-03$ & 03:21 & 100 & 0 \\
\hline 18 & $02-06-03$ & $03: 47$ & 0 & 0 \\
\hline 19 & $02-06-03$ & 05:04 & 250 & 0 \\
\hline 20 & $02-06-03$ & $05: 28$ & 100 & 200 \\
\hline 21 & $02-06-03$ & $06: 15$ & 0 & 500 \\
\hline 22 & $02-06-03$ & $06: 31$ & 200 & 1000 \\
\hline 23 & $02-06-03$ & $07: 35$ & 2000 & 0 \\
\hline 24 & $02-06-03$ & $07: 55$ & 5500 & 0 \\
\hline 25 & $02-06-03$ & 09:31 & 2500 & I \\
\hline 26 & 02-06-04 & 06:04 & 0 & 0 \\
\hline 27 & 02-06-04 & $06: 30$ & 0 & 0 \\
\hline 28 & 02-06-04 & $10: 15$ & 250 & I \\
\hline 29 & 02-06-04 & $10: 27$ & 2000 & I \\
\hline 30 & 02-06-04 & $11: 19$ & 3000 & I \\
\hline 31 & 02-06-04 & $12: 22$ & 3500 & I \\
\hline 32 & 02-06-10 & 06:03 & 0 & 0 \\
\hline 33 & 02-06-10 & $07: 24$ & 100 & 0 \\
\hline 34 & 02-06-10 & 07:51 & 0 & I \\
\hline 35 & $02-06-10$ & 08:49 & 0 & I \\
\hline 36 & $02-06-11$ & $05: 55$ & 300 & 0 \\
\hline 37 & 02-06-11 & $06: 45$ & 8000 & I \\
\hline 38 & $02-06-11$ & 07:04 & 5000 & I \\
\hline 39 & 02-06-11 & $07: 46$ & 10000 & I \\
\hline 40 & 02-06-11 & 08:20 & 7000 & I \\
\hline
\end{tabular}

To characterize the development of the boundary layer at the Melpitz site, a monostatic Doppler SODAR (MODOS, manufactured by METEK GmbH, Elmshorn, Germany) was used. It measures the backscattered signal intensity $S$ and the Doppler shift of reflected sound pulses. From $S$, which

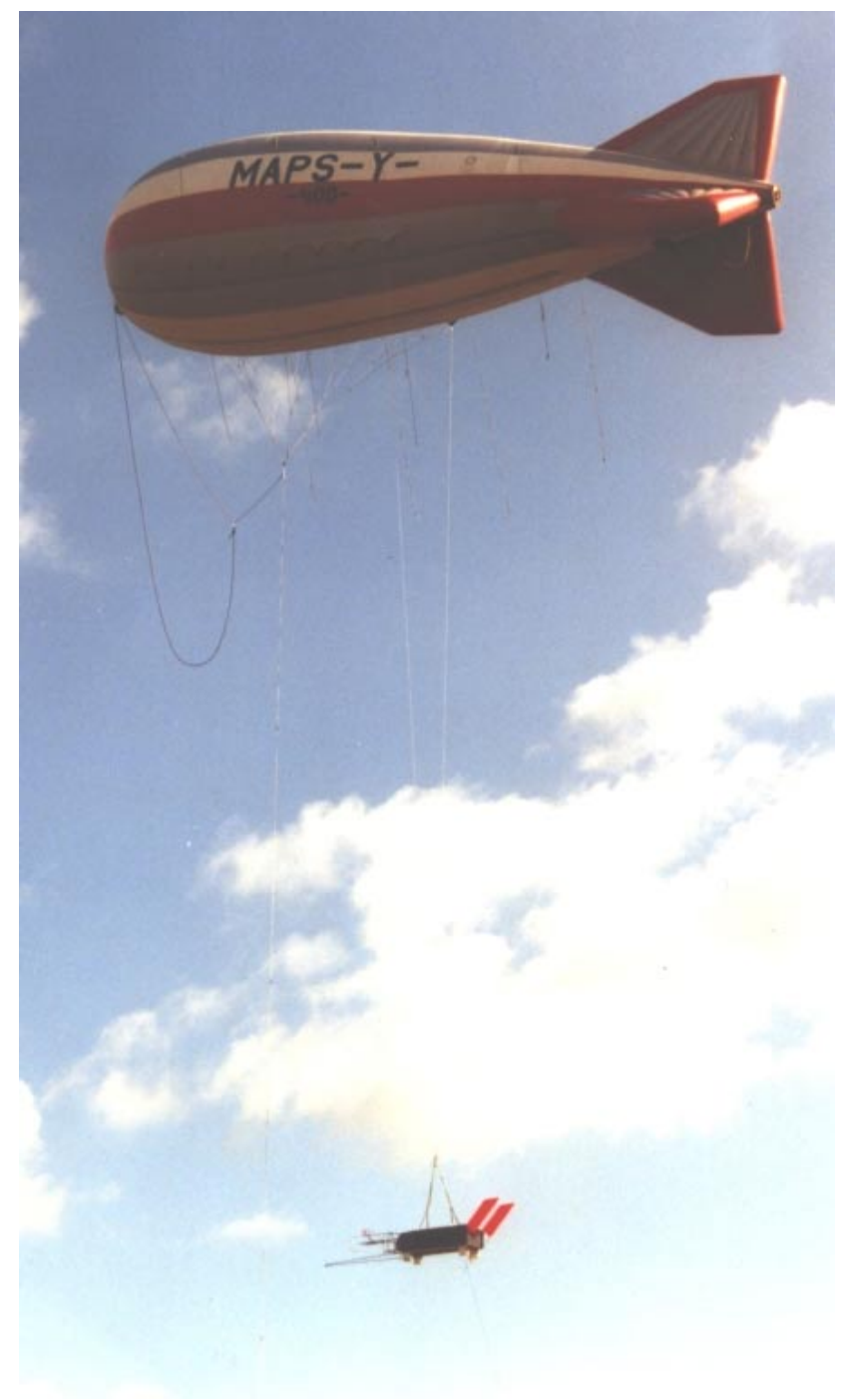

Fig. 3. The tethered-balloon MAPS-Y with the suspended payload ACTOS.

is mainly influenced by small temperature fluctuations, the height of the inversion layer can be estimated. The threedimensional wind vector is derived from the Doppler shift. The instrument was operated on a continuous basis during the whole SATURN experiment. A more detailed introduction about acoustic remote sensing can be found in Neff and Coulter (1986).

Furthermore, radiosondes were launched during the whole measurement period several times each day. Two different types of radiosondes (Graw DFM90 and Vaisala RS80-A) were utilized to measure profiles of temperature, pressure, and relative humidity. As the Graw types were additionally equipped with a GPS receiver, they were applied to determine the actual wind velocity and direction.

$\mathrm{SO}_{2}$ and $\mathrm{NH}_{3}$ concentrations were measured at the Melpitz site on a continuous basis. 


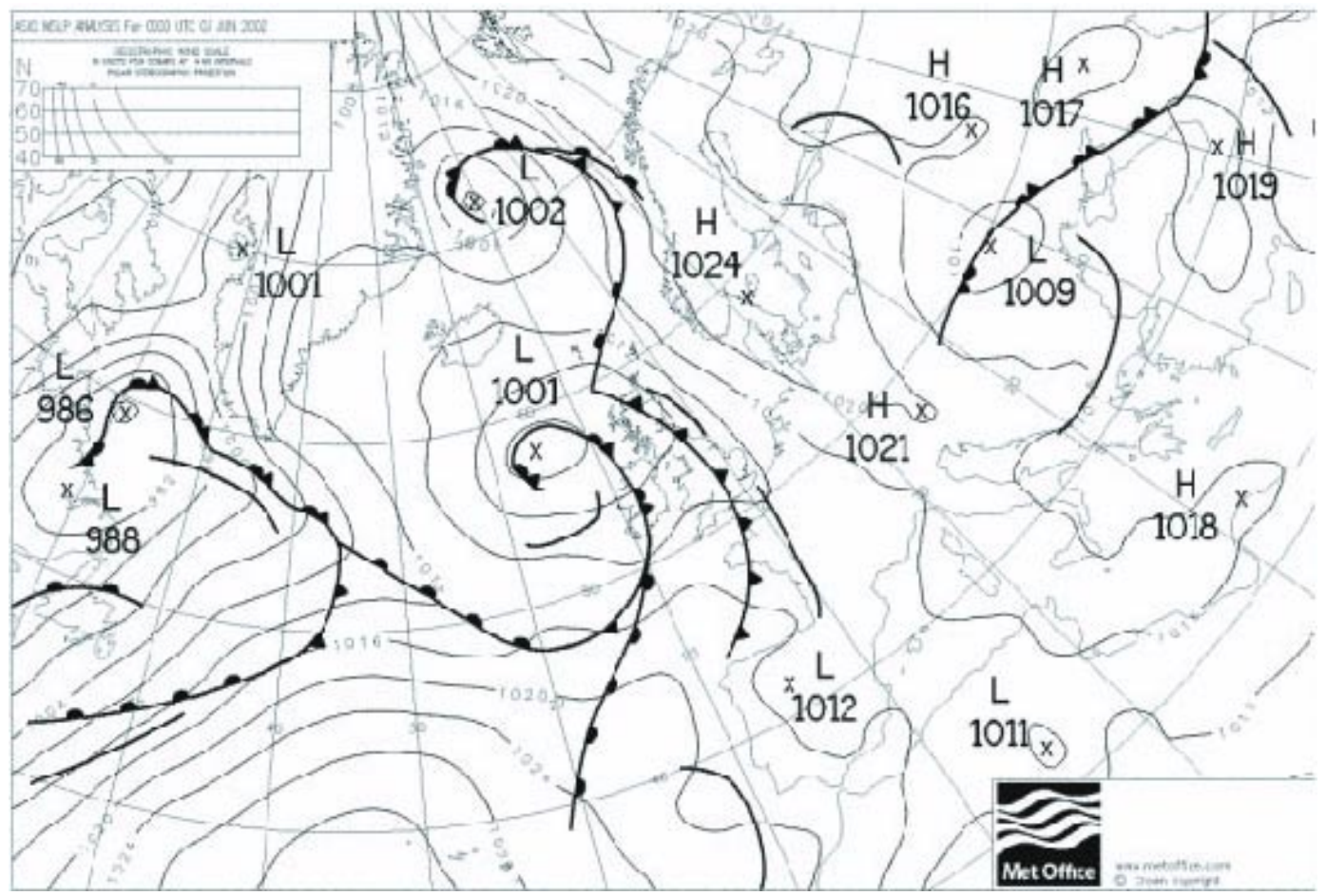

Fig. 4. Surface chart of the synoptic situation on 3 June 2002.

For the $\mathrm{SO}_{2}$ measurements a pulsed fluorescence gas monitor (Model 43s, Thermo Environmental Instruments Inc., USA) was used. For calibration, trace gas quantities of $\mathrm{SO}_{2}$ prepared from a test gas cylinder with audit certificate (Messer Griesheim, Germany) in combination with a gas mixer (Environics 2000, USA), were used.

Ammonia was measured with a wet annular denuder system (Slanina et al., 1992; Wyers et al., 1993). The analysis in this system is made by membrane diffusion of $\mathrm{NH}_{3}$ at high $\mathrm{pH}$ into a counter flow of de-ionized water, with an online measurement of conductivity.

2.4 Ground-based measurements of particle size distributions

Particle number size distributions were measured in the particle size range $3<D_{p}<800 \mathrm{~nm}$ at all three measurement sites. For that purpose, Twin Differential Mobility Particle Sizer (TDMPS) systems were used (designed by Birmili et al., 1999) comprising two size spectrometers that simultaneously measure different particle size ranges at dry conditions. $\mathrm{Nu}-$ cleation mode particles $\left(3<D_{p}<22 \mathrm{~nm}\right)$ were measured with an Ultrafine Differential Mobility Analyzer (Hauke type) in conjunction with an Ultrafine Condensation Particle Counter (UCPC, Model 3025, TSI Inc., St. Paul, MN, USA). Particles in the range from $22<D_{p}<800 \mathrm{~nm}$ were measured by means of a Differential Mobility Analyzer (Hauke type) and a CPC (TSI-Model 3010). In Melpitz, the total particle num- ber concentration $\left(3<D_{p}<1000 \mathrm{~nm}\right)$ was additionally measured using a UCPC (TSI-Model 3025). The inlets used at the three sites were commercially available low-flow PM10 inlets (Thermo Anderson, Smyrna, GA, USA).

\subsection{LIDAR}

To gain information about structure and development of the planetary boundary layer (PBL), a multiwavelength aerosol Raman lidar (Mattis et al., 2002) was used at the IfT site. This instrument delivers the particle volume $180^{\circ}$ backscatter coefficient at 355, 532, and $1064 \mathrm{~nm}$ wavelength and the particle volume extinction coefficients at 355 and $532 \mathrm{~nm}$ wavelenght as well as temperature and watervapor mixing ratios. The LIDAR is part of the European Aerosol Research Lidar Network (EARLINET, Bösenberg et al., 2001).

\section{Meteorological situation}

The SATURN experiment took place from 27 May to 14 June 2002. During this time period new-particle formation events were observed on 8 days. This paper focus on observations conducted on 3 June 2002.

The synoptical situation on 3 June 2002 is depicted in Fig. 4. During this day, the weather in central Europe was mainly influenced by a high-pressure system ranging from northern Scandinavia over central Europe to the south-east 

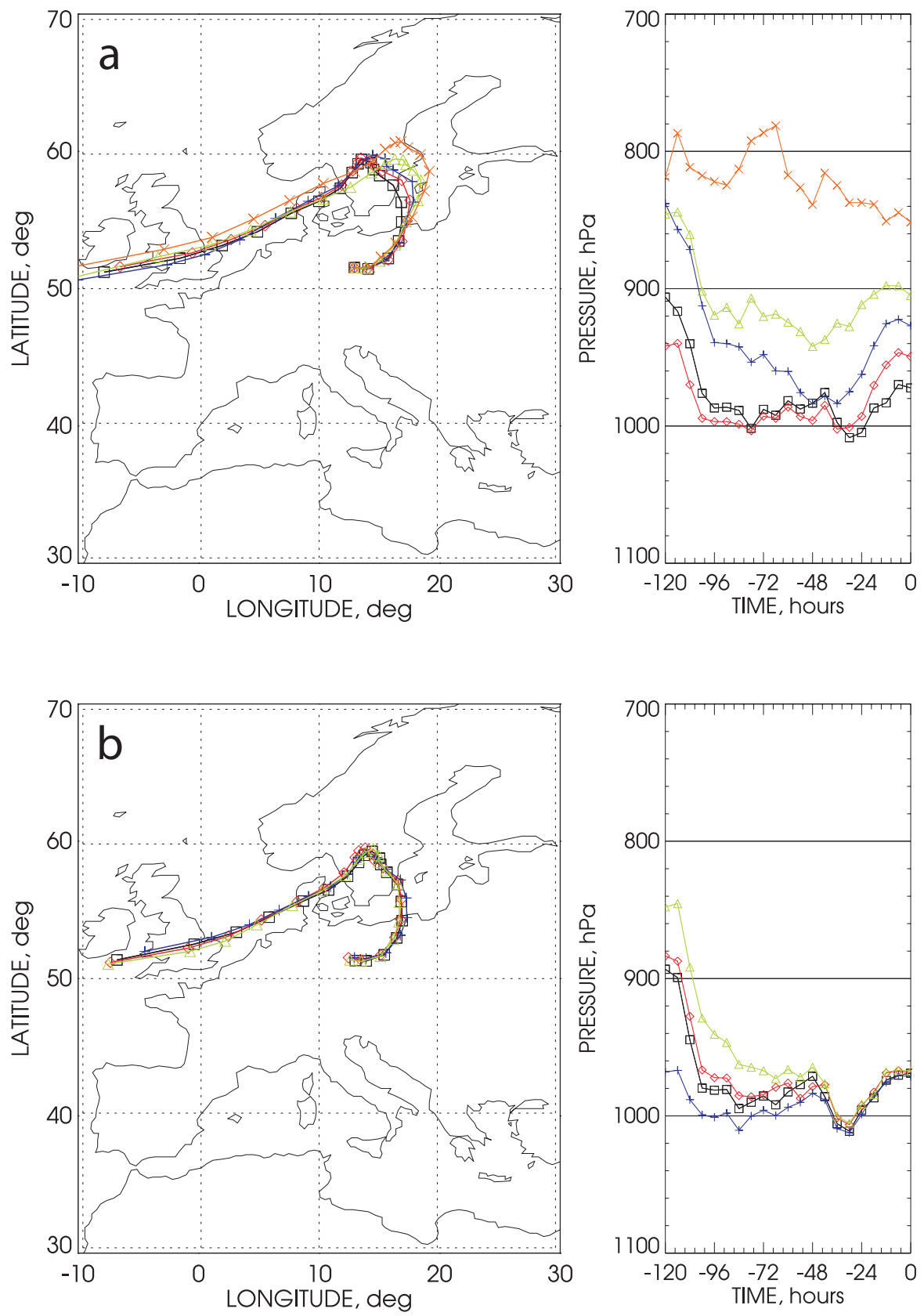

Fig. 5. Backward trajectories with arrival at (a) Melpitz on 3 June 2002, 09:00 UTC, and (b) Collm (black), Leipzig (red), Melpitz (blue), and Panitzsch (green) on 3 June 2002, 11:00 UTC. The arrival heights are (a) 400 (black), 600 (red), 800 (blue), 1000 (green), and $1500 \mathrm{~m}$ asl (orange) and (b) $400 \mathrm{~m}$ asl (right panels, time 0 ). The left panels present a horizontal projection of the trajectories with their positions marked every 6 hours.

of the Mediterranean. A low-pressure system with its frontal system west of Great Britain had no influence on the weather at the experimental site. Calm winds from southeasterly directions and sunny weather prevailed on 3 June 2002. Only a few convective clouds developed at noon.

Figure 5 shows a 120-h sequence of the backward trajectories for arrival heights of 400,600,800,1000, and $1500 \mathrm{~m}$ asl at Melpitz at 09:00 UTC and for an arrival height of $400 \mathrm{~m}$ asl at the stations Collm, Leipzig, Melpitz, and Panitzsch at
11:00 UTC. These three-dimensional backward trajectories were calculated with the flexible trajectory model FLEXTRA (version 3.2d) (Stohl et al., 1995). FLEXTRA was driven with hemispheric model-level wind fields provided by the European Centre for Medium-Range Weather Forecasts (T511 L60 model, ECMWF, 1995), with a horizontal resolution of $0.5^{\circ}$ and a time resolution of $3 \mathrm{~h}$ (analyses at $0,6,12$, 18 UTC; 3-h forecasts at 3, 9, 15, 21 UTC). 


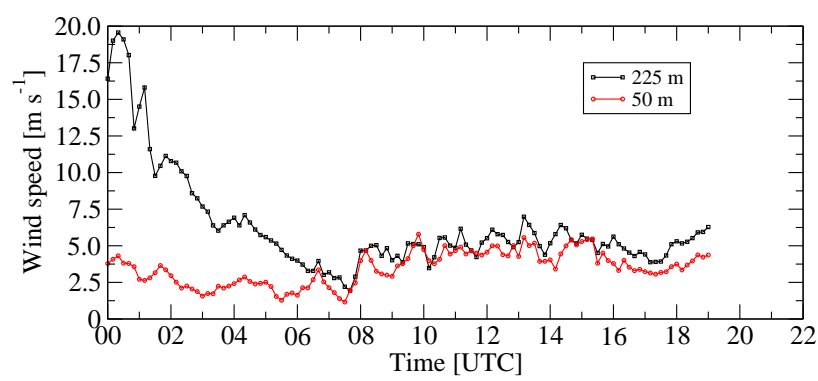

Fig. 6. Time series of the horizontal wind speed in 50 and $225 \mathrm{~m}$ as measured with SODAR in Melpitz on 3 June 2002.

The air was advected from the North Atlantic, crossed Great Britain, the North Sea, and southern Scandinavia. Then the flow turned south-westward over the Baltic Sea. For about $24 \mathrm{~h}$ the air mass traveled over continental sites in northern Poland before it reached the experimental area from the East. The flow pattern in the lowest $1500 \mathrm{~m}$ of the atmosphere did not change significantly, neither with time nor with height, during the entire day. Only the turning point over the Baltic Sea moved slowly eastward. This movement caused the air masses that arrived in the late afternoon to spend an additional 6-12 $\mathrm{h}$ over land.

Figure 6 shows time series of the horizontal wind speed in 50 and $225 \mathrm{~m}$ on the June 3, 2002 in Melpitz, as measured with the SODAR system. The horizontal wind speed in $50 \mathrm{~m}$ was about $3-4 \mathrm{~m} \mathrm{~s}^{-1}$ during night and increased slightly in the morning (around 08:00 UTC) to values of 4-6 $\mathrm{m} \mathrm{s}^{-1}$ over the day. In the first part of the day much higher values of the wind speed were observed in $225 \mathrm{~m}$. After the maximum of $20 \mathrm{~m} \mathrm{~s}^{-1}$ was reached between 00:00 and 01:00 UTC, the wind speed decreased until 07:00 UTC to values similar to those measured in $50 \mathrm{~m}$. This increased wind speed is due to a shallow low-level jet which occurred during night in the stable boundary layer (SBL) close to the inversion. For a general description of the PBL the reader is referred to textbooks like e.g., Stull (1988). The lack of data after 19:00 UTC is due to a negative signal-to-noise ratio for the level in $225 \mathrm{~m}$.

Figure 7 shows a time-height contour plot of the backscattered signal intensity $S$ measured with SODAR for the same time as Fig. 6. According to Beyrich and Weill (1993) the height of the SBL (resp. the nocturnal inversion layer (IL) depth) is indicated by the maximum of the vertical gradient of the signal $S$. In Fig. 7 a local maximum of this gradient is identified around $200 \mathrm{~m}$ between 00:00 and 03:00 UTC. After 03:00 UTC (sunrise) the gradient became smaller and the height of the maximum varied between 150 and $260 \mathrm{~m}$. Around 07:00 to 07:30 UTC the nocturnal IL broke up and intensive vertical mixing started. Within about one hour the mixed layer (ML) rose from about $260 \mathrm{~m}$ to higher than the ceiling of the SODAR. After sunset (19:20 UTC) again a strong vertical gradient of $S$ with a maximum in about $150 \mathrm{~m}$ developed.

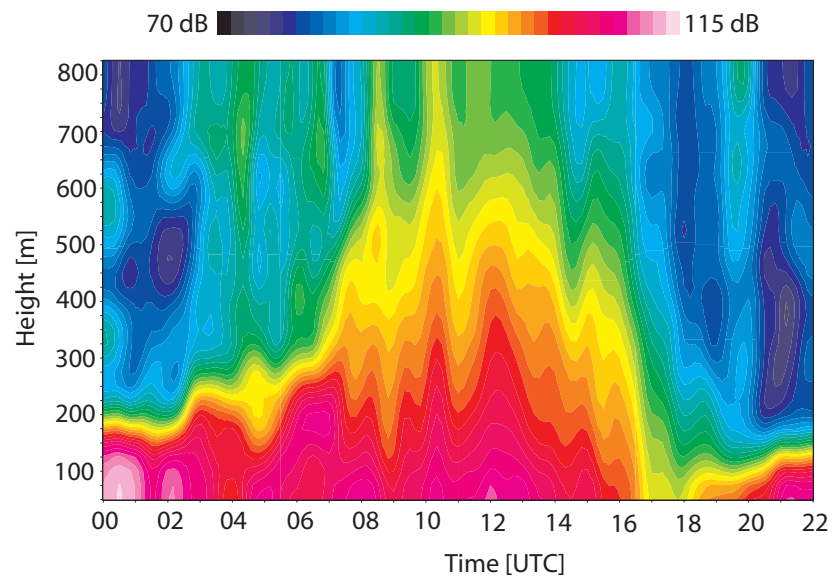

Fig. 7. Height-time contour plot of the back-scattered signal intensity $S$ as measured with SODAR in Melpitz on 3 June 2002. Sunrise is at 03:00 UTC, sunset is at 19:20 UTC, respectively.

Figure 8 shows four vertical profiles of temperature $T$ (left) and absolute humidity $a$ (right) as measured with radiosondes (Vaisala RS80). The first two profiles (launched at 05:30 and 06:30 UTC) show the pronounced IL with positive temperature gradients of $+2.4 \mathrm{~K}(100 \mathrm{~m})^{-1}$ below $260 \mathrm{~m}$. In the residual layer (RL), between the inversion and about $1000 \mathrm{~m}$, the gradient is $-0.9 \mathrm{~K}(100 \mathrm{~m})^{-1}$, that is, this layer is neutrally stratified. Above the RL, the atmosphere is slightly stably stratified with a mean gradient of about $-0.65 \mathrm{~K}(100 \mathrm{~m})^{-1}$. The solid lines with the gradients in Fig. 8 refer to the sounding from 06:30 UTC. The next two profiles (07:30 and 09:30 UTC) show the situation after the inversion broke up, no inversion can be found over the complete profile. This is in good agreement with the SODAR measurements. The humidity profiles show a local maximum below the inversion (first two profiles). A second jump is seen in $1000 \mathrm{~m}$, which is also an indication for the height of the RL. After the ground inversion disappeared, the humidity profiles show no significant structures up to the PBL height in $1200 \mathrm{~m}$ (07:30 UTC) and $1400 \mathrm{~m}$ (09:30 UTC), respectively.

Figure 9 shows the development of the PBL between 04:30 UTC and 19:50 UTC on 3 June 2002, as measured with LIDAR at the IfT site in Leipzig. The time-height contour plot represents a measure of relative particle back-scattering:

$P_{r e l}(z)=\frac{P(z)-\bar{P}(z)}{\bar{P}(z)}$.

Here $P(z)$ is the actual LIDAR signal at height $z$ detected with a resolution of $60 \mathrm{~m}$ and $30 \mathrm{~s}$ and $\bar{P}(z)$ is the average signal at height $z$ for a given measurement period. The periods are separated by white vertical bars in Fig. 9. Relative back-scatter values are shown, because measurements close to the LIDAR (i.e., close to the ground) are usually biased by the incomplete overlap between the laser beam and the 

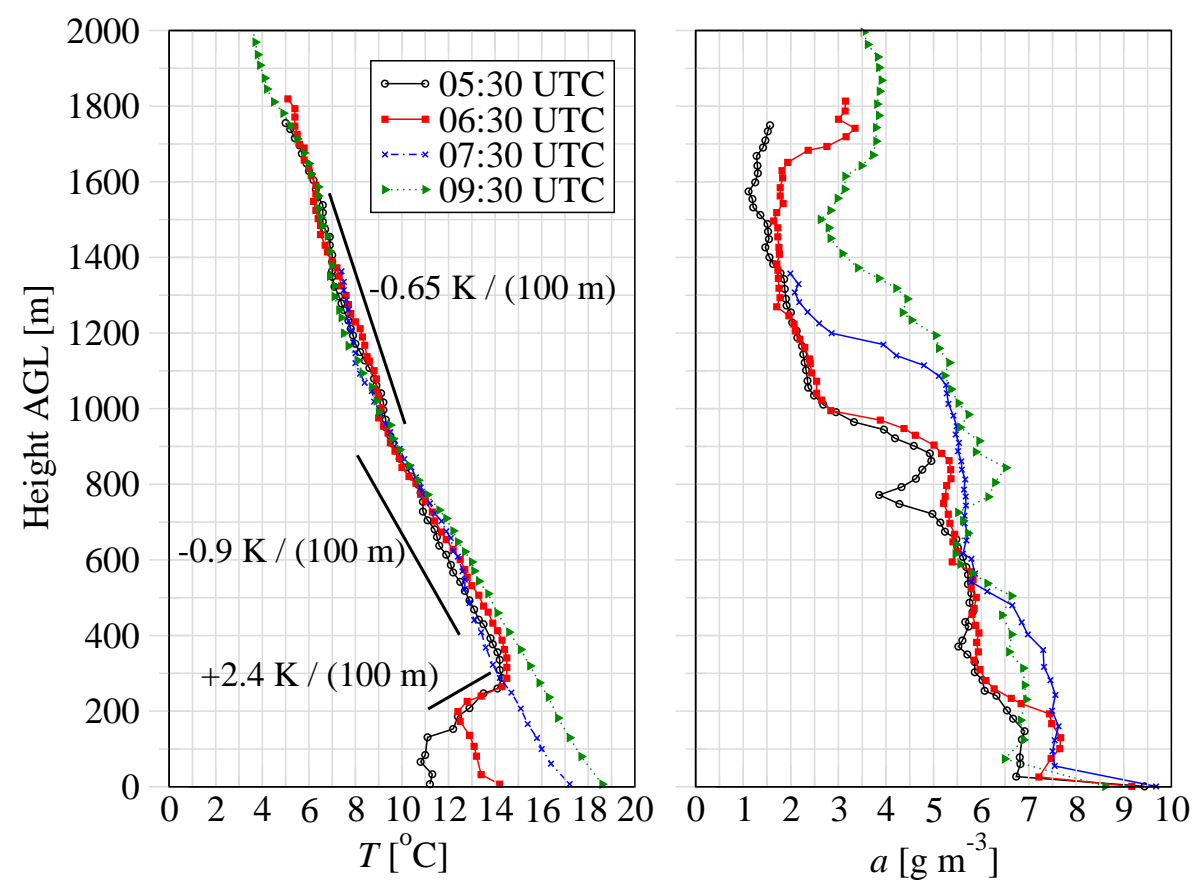

Fig. 8. Vertical profiles of temperature $T$ and absolute humidity $a$ as measured with radiosondes at the Melpitz site. The depicted gradients are related to the sounding from 06:30 UTC.

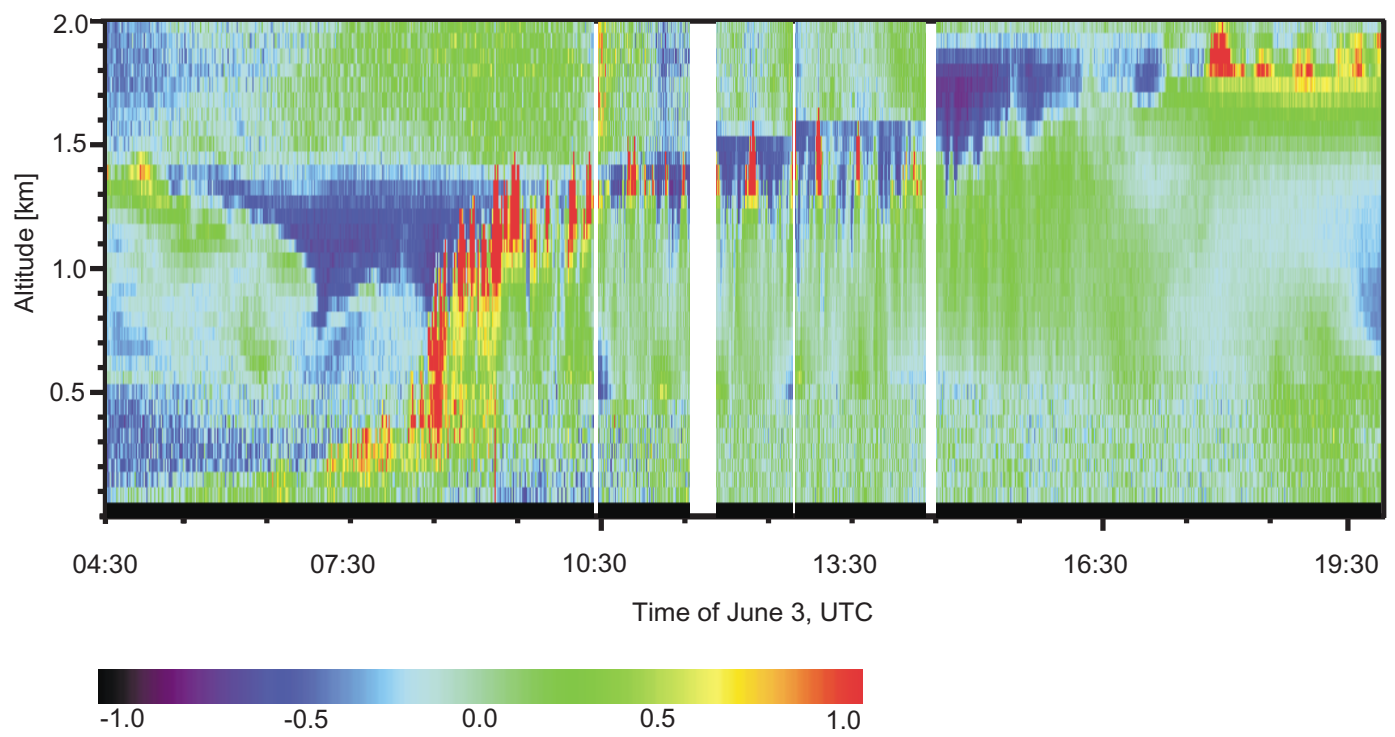

Fig. 9. Development of the planetary boundary layer in terms of the relative back-scatter signal at 1064 nm observed with the IfT Raman LIDAR at Leipzig on 3 June 2002. The resolution is $60 \mathrm{~m}$ and $30 \mathrm{~s}$.

receiver's field of view. In the case of relative back-scattering after Eq. (1) this overlap effect is canceled out. Thus, the observations cover the entire PBL. Note that the LIDAR is sensitive to optically active particles only, i.e., back-scattering is dominated by particles with diameters $>100 \mathrm{~nm}$.

According to Eq. (1), bluish-green colors in Fig. 9 $\left(P_{r e l} \sim 0\right)$ indicate atmospheric regions with marginal changes in particle back-scattering, whereas blue $\left(P_{r e l}<0\right)$ and red colors $\left(P_{r e l}>0\right)$ show strong negative and positive deviations from the mean, respectively. A rapid change between red and blue colors marks the atmospheric height regions of strongest dynamic activity, where particle-rich air is transported upwards and cleaner air moves downward. The SBL is observed in $200 \mathrm{~m}$ height between 04:30 and about 


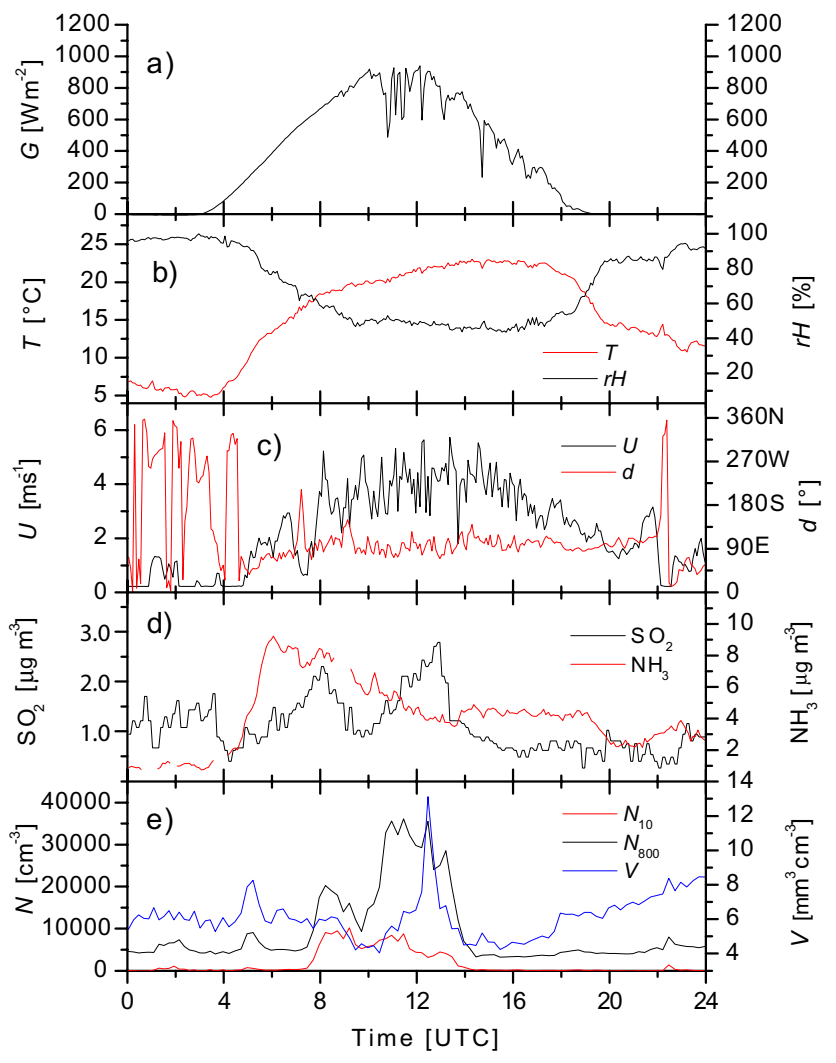

Fig. 10. Diurnal variation of global radiation $G$, temperature $T$, relative humidity $r H$, wind speed $U$, wind direction $d, \mathrm{SO}_{2}, \mathrm{NH}_{3}$, particle number concentration $\left(N_{10}: 3-10 \mathrm{~nm}\right.$ and $\left.N_{800}: 3-800 \mathrm{~nm}\right)$ and particle volume concentration $V$ in Melpitz on 3 June 2002, at ground.

07:00 UTC. First up-drafts developed below $400 \mathrm{~m}$ height between 07:00 and 08:00 UTC. A rapid increase of the mixed layer from 300 to $1400 \mathrm{~m}$ associated with strong dynamic activity was observed between 08:00 and 09:30 UTC. From 09:30 to 15:00 UTC only slight variations of the PBL height around $1500 \mathrm{~m}$ occurred. In the late afternoon, a further increase of the PBL height to values around $1700 \mathrm{~m}$, probably associated with a change in the air-mass, was found.

At both experimental sites, Melpitz and Leipzig, a similar development of the PBL was observed. During the cloudless night, a SBL developed about $200 \mathrm{~m}$ in depth. Above the inversion, the RL up to $1000 \mathrm{~m}$ in Melpitz and about $1400 \mathrm{~m}$ in Leipzig was clearly identified. Extensive vertical mixing started after the inversion broke up at both sites. At the Melpitz site, the first plumes reached heights of $500 \mathrm{~m}$ at about 08:00 UTC, while at Leipzig this height was reached about $0.5 \mathrm{~h}$ later. This time shift might be due to cirrus clouds which were observed above Leipzig but not over Melpitz. These clouds may delay the warming of the lower air masses and, therefore, the convective mixing of the PBL.

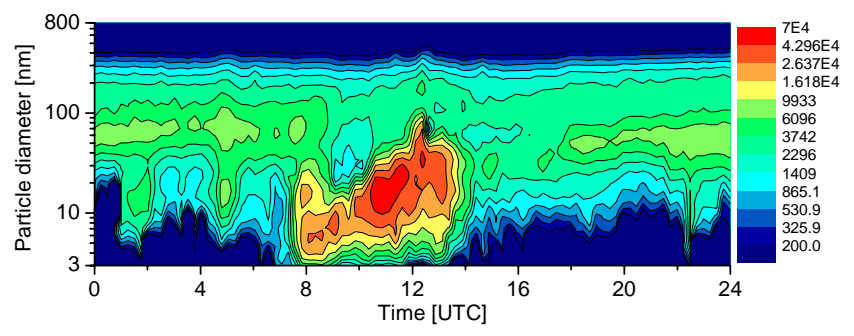

Fig. 11. Diurnal variation of number size distributions in Melpitz on 3 June 2002.

\section{Observations in Melpitz}

\subsection{Ground-based observations}

Figure 10 shows results from the ground-based measurements of global radiation $G$, temperature $T$, relative humidity $R H$, wind speed $v$, wind direction $d, \mathrm{SO}_{2}$, and $\mathrm{NH}_{3}$ concentration, particle number concentrations $N(3-10 \mathrm{~nm}$ and $3-800 \mathrm{~nm}$ ) and calculated particle volume concentration $V$ as function of time as determined in Melpitz on 3 June 2002. From Figs. 10a-c, it can be seen, that 3 June featured an increase in global radiation (a radiation maximum near $1000 \mathrm{~W} \mathrm{~m}^{-2}$ ) and temperature, and decreasing relative humidity during morning hours, i.e., a behavior attributed to typical clear-sky days. Around 10:00 UTC the global radiation decreased and varied afterwards due to small cumulus clouds. The wind speed was close to zero during the night and increased up to $4 \mathrm{~ms}^{-1}$ during the day forced by convection. The mean wind direction during the day was from east.

The $\mathrm{SO}_{2}$ concentration (Fig. 10d) shows two peaks, the first one at 08:00 UTC, i.e., half to one hour after the breakup of the nocturnal inversion layer (up to $900 \mathrm{ppt}$ ) and a second one at 12:00 UTC (up to $1050 \mathrm{ppt}$ ). The ammonia concentration (Fig. 10d) increases fast in the early morning from 1 up to $9 \mu \mathrm{g} \mathrm{m}^{-3}$. During daytime the $\mathrm{NH}_{3}$ concentration is about $4-6 \mu \mathrm{g} \mathrm{m}^{-3}$.

As can be seen in Fig. 10e, the number concentrations $\left(N_{10}: 3-10 \mathrm{~nm}\right.$ and $\left.N_{800}: 3-800 \mathrm{~nm}\right)$ show a significant increase at 07:30 UTC. Both number concentrations feature a second maximum between 10:30 and 12:00 UTC, i.e., shortly after the appearance of small cumulus clouds (Fig. 10 a). The evolution of $N_{10}$ and $N_{800}$ seems to be connected to the evolution of the $\mathrm{SO}_{2}$ concentration. However, for the second maximum in $N_{10}$, this is less pronounced.

The volume concentration, as calculated from the number size distribution shows no correlation with the first morning maximum, it is even slightly decreasing between 08:00 and 10:00 UTC.

In Fig. 11 the diurnal variation of the number size distributions as measured at the Melpitz site is shown. As to been seen from this figure, the diurnal variation of the number size 


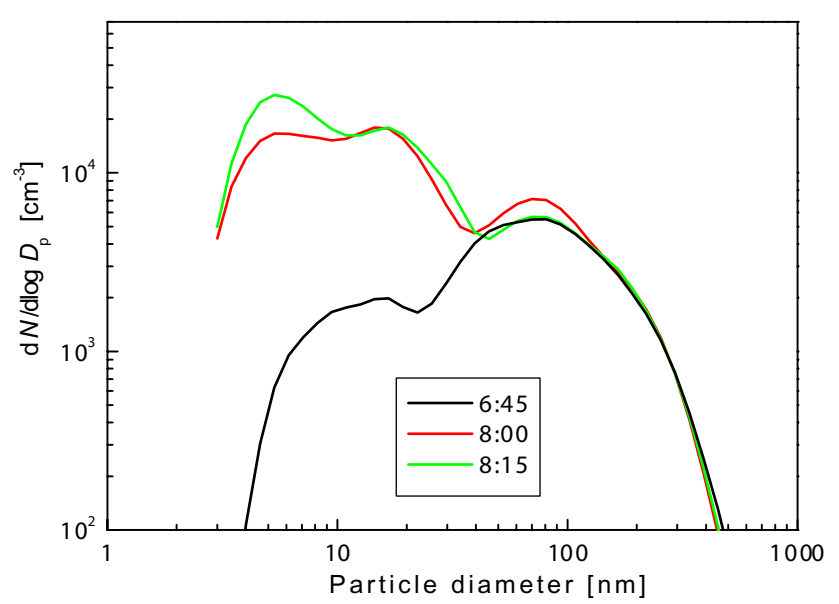

Fig. 12. Number size distributions as measured at 06:45, 08:00, and 08:15 UTC in Melpitz on June 3, 2002.

distributions is similar to the behavior of $N_{10}$ and $N_{800}$. Approximately at 07:30 UTC, analogue to Fig. 10e, a rapid increase in number concentration of particles with diameters between 3 and $20 \mathrm{~nm}$ is observed. This increase takes place half an hour after the break-up of the nocturnal inversion at around 07:00 UTC (see Fig. 7) and coincides with the first maximum in $\mathrm{SO}_{2}$ concentration (Fig. 10d). In the particle size range below $20 \mathrm{~nm}$, the particle size distribution at this time is bimodal featuring local maxima at approximately 5 and $15 \mathrm{~nm}$. With increasing time, the maximum at $5 \mathrm{~nm}$ shifts towards larger sizes and becomes more pronounced while the maximum at $15 \mathrm{~nm}$ disappears after approximately $1 \mathrm{~h}$. Between 10:30 and 12:00 UTC (see also Fig. 10e), an absolute maximum located around $20 \mathrm{~nm}$ appears. The occurrence of this maximum coincides with the appearance of small cumulus clouds (see Fig. 10a) and is in some degree correlated with the second increase in $\mathrm{SO}_{2}$ concentration (see also Figs. 10d and e). To point out the significant size distribution changes taking place in the course of the break-up of the nocturnal inversion, Fig. 12 depicts number size distributions observed at 06:45, 08:00, and 08:15 UTC, i.e., before and during the break-up of the nocturnal inversion. Below $20 \mathrm{~nm}$, the distribution measured at 06.45 features a single local maximum around $15 \mathrm{~nm}$, while the distributions taken at 08:00 and 08:15 exhibit two pronounced local maxima at approximately 5 and $15 \mathrm{~nm}$. Between 06:45 and 08:15 UTC, the size distribution values change by two and one order of magnitude for particle sizes of 5 and $15 \mathrm{~nm}$, respectively.

The ground-based observations at the Melpitz site showed, that newly formed particles occur about 0.5 to $1 \mathrm{~h}$ after the break-up of the nocturnal inversion until the mixing layer has reached the top of the PBL in around $1000 \mathrm{~m}$ after a few hours (cf. Fig. 9 for Leipzig). Assuming a) that new particle formation is induced by the break-up of the nocturnal inversion after 07:00 UTC, b) a particle diameter of $1 \mathrm{~nm}$ for the

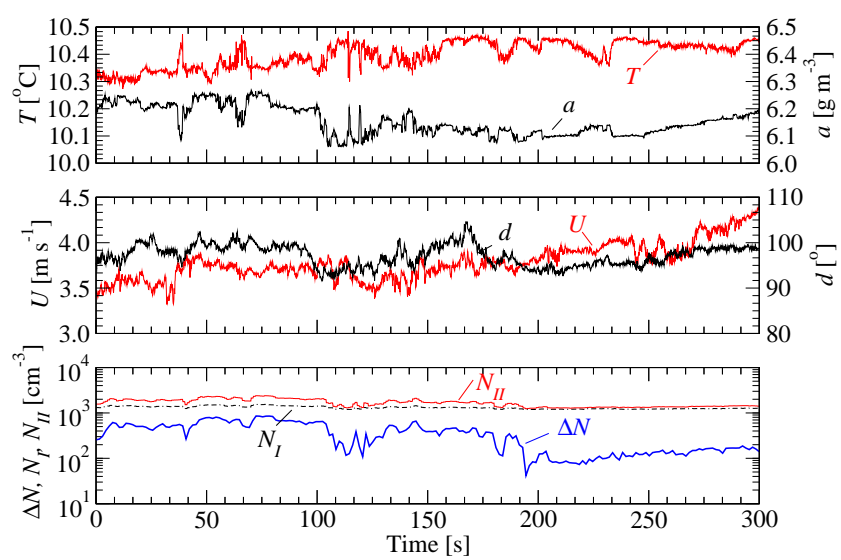

Fig. 13. Time series of temperature $T$, absolute humidity $a$, horizontal wind speed $U$, wind direction $d$, particle number concentration $N_{I}\left(10<D_{p}<1500 \mathrm{~nm}\right), N_{I I}\left(5<D_{p}<1500 \mathrm{~nm}\right)$, and $\Delta N$ $\left(5<D_{p}<10 \mathrm{~nm}\right)$ at constant level in $830 \mathrm{~m}$ (06:26-06:30 UTC).

freshly nucleated particles, and c) considering a particle size of $5 \mathrm{~nm}$ as measured around 08:00 UTC, a growth rate of $4 \mathrm{~nm} / \mathrm{h}$ within the first hour can be estimated. This growth rate is smaller but in the same range as the one suggested by Lehtinen and Kulmala (2003). Although this is a very crude estimation, it may be concluded that assumption a) is valid and thus new particle formation maybe induced by the break-up of the nocturnal inversion. The occurrence of the second local size distribution maximum around $15 \mathrm{~nm}$ maybe explained by the mixing down of particles that were newly formed and grew up to larger sizes inside the RL before the break-up of the nocturnal inversion. Performing again a crude estimation, i.e., assuming a) that new particle formation in the RL starts at sunrise around 03:00 UTC, b) a particle diameter of $1 \mathrm{~nm}$ for the freshly nucleated particles, and c) considering a particle size of $15 \mathrm{~nm}$ as measured around 08:00 UTC, a growth rate of approximately $3 \mathrm{~nm} / \mathrm{h}$ can be estimated. Again this crudely estimated growth rate has to be considered reasonable. This together with the balloonborne observations described below supports the hypothesis that the second local size distribution maximum around $15 \mathrm{~nm}$ maybe explained by the mixing down of particles that were newly formed in the RL.

\subsection{Balloon-borne observations}

Several vertical profiles and time series at a constant level were measured with ACTOS in Melpitz on June 3, 2002.

The first time series (Fig. 13) was measured at a height of $830 \mathrm{~m}$ from 06:26 to 06:30 UTC in the RL well above the inversion at $200 \mathrm{~m}$. The time series of $T$ and $a$ show strong fluctuations with standard deviations of about $\sigma_{T}=0.05 \mathrm{~K}$ and $\sigma_{a}=0.08 \mathrm{~g} \mathrm{~m}^{-3}$, respectively. Most of the fluctuations of the thermodynamic variables were observed within the first $200 \mathrm{~s}$. The mean horizontal wind speed $U$ 


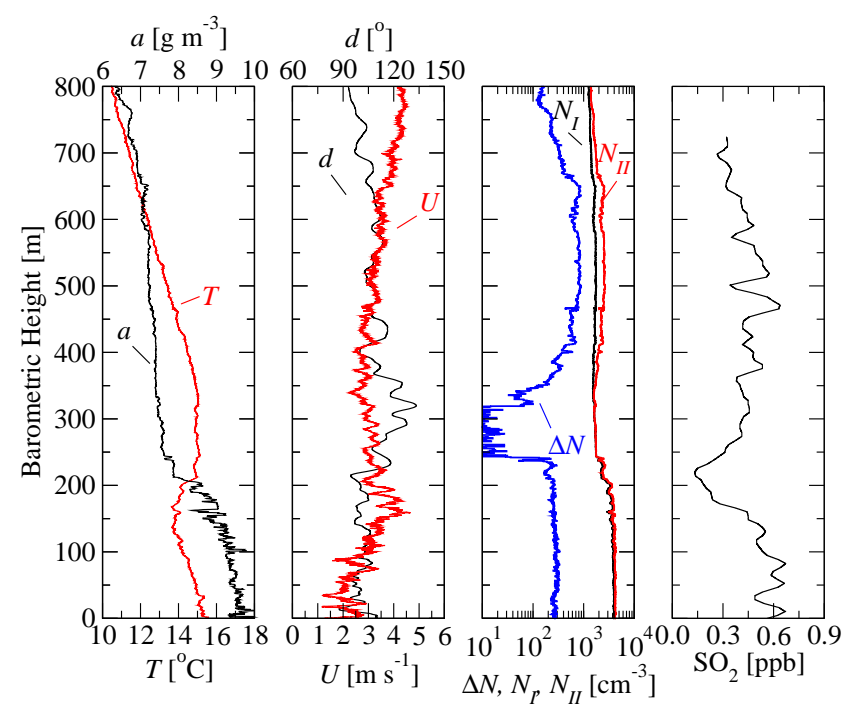

Fig. 14. Vertical profile (descent from $830 \mathrm{~m}$ to ground, 06:3106:53 UTC) of temperature $T$, absolute humidity $a$, horizontal wind speed $U$, wind direction $d$, particle number concentration $N_{I}\left(10<D_{p}<1500 \mathrm{~nm}\right), N_{I I}\left(5<D_{p}<1500 \mathrm{~nm}\right), \Delta N$ $\left(5<D_{p}<10 \mathrm{~nm}\right)$, and $\mathrm{SO}_{2}$.

was $3.8 \pm 0.15 \mathrm{~m} \mathrm{~s}^{-1}$ from easterly directions. Particle number concentrations are plotted on a logarithmic scale. For the particles between 10 and $1500 \mathrm{~nm}$ the concentration $N_{I}$ was around $1300 \pm 100 \mathrm{~cm}^{-3}$ whereas the concentration $N_{I I}$ which includes the smaller particles was at $1700 \pm 320 \mathrm{~cm}^{-3}$. Small particles show maximum concentrations $\Delta N$ of several $100 \mathrm{~cm}^{-3}$ in the first $200 \mathrm{~s}$ where $\sigma_{T}$ and $\sigma_{a}$ are higher.

Results from the following descent (starting at 06:31 UTC) from $830 \mathrm{~m}$ to ground are plotted in Fig. 14. The temperature profile indicates an inversion between 150 and $200 \mathrm{~m}$ with a mean gradient of about $+2.8 \mathrm{~K}(100 \mathrm{~m})^{-1}$. Between 200 and $330 \mathrm{~m}$ the gradient is close to zero. For higher altitudes the profile shows an adiabatic lapse rate of $-1 \mathrm{~K}(100 \mathrm{~m})^{-1}$.

The water-vapor density shows strong fluctuations inside the ML with a slight decrease in the inversion from about 9.5 to $7 \mathrm{~g} \mathrm{~m}^{-3}$. In the first $100 \mathrm{~m}$ above ground, $U$ is close to $2 \mathrm{~m} \mathrm{~s}^{-1}$ and exhibits a local maximum around the inversion. In the RL, $U$ varies between 3 and $4 \mathrm{~m} \mathrm{~s}^{-1}$ from easterly directions. The number concentration profiles show a clear cut between the ML, inversion, and RL. Inside the ML, $N_{I I}$ is nearly constant with height and includes about 250 particles $\mathrm{cm}^{-3}$ smaller than $10 \mathrm{~nm}$. In a narrow region above the inversion (between 250-300 m), no small particles could be observed. Above, $\Delta N$ increases up to values of $800 \mathrm{~cm}^{-3}$ between 400 and $600 \mathrm{~m}$. In this layer, $\Delta N$ varies in the same range as in the time series shown in Fig. 13. A similar behavior can be observed for the $\mathrm{SO}_{2}$ concentration profile, which features a minimum around $220 \mathrm{~m}$. Due to the response time of the $\mathrm{SO}_{2}$ monitor, which is in the order of 20 to $60 \mathrm{~s}$ (corresponding to 30 to $80 \mathrm{~m}$ in barometric height) this minimum is shifted downwards.

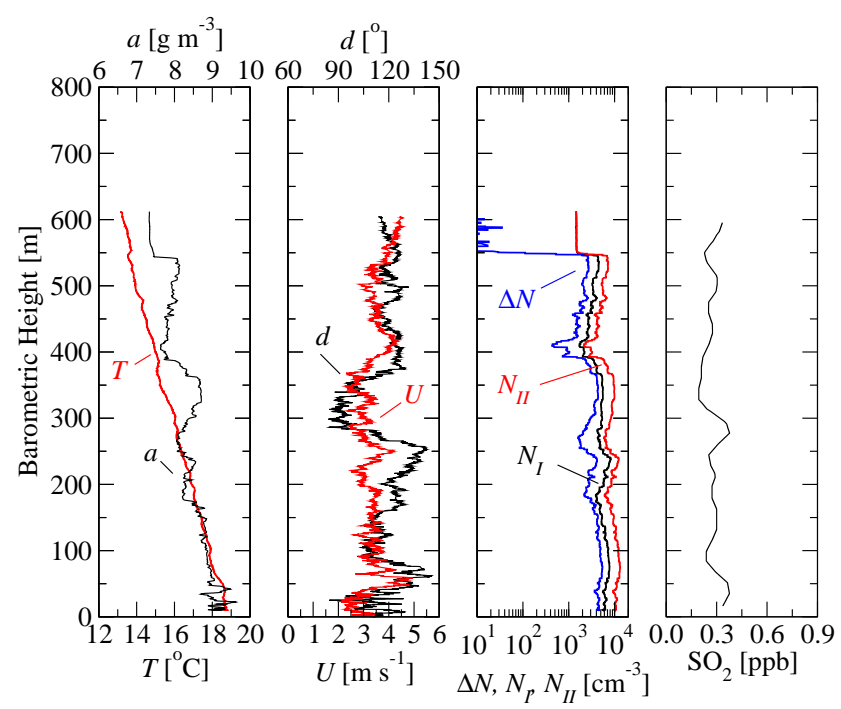

Fig. 15. Vertical profile (ascent from ground to $610 \mathrm{~m}, 08: 43-$ 08:48 UTC) of temperature $T$, absolute humidity $a$, horizontal wind speed $U$, wind direction $d$, particle number concentration $N_{I}\left(10<D_{p}<1500 \mathrm{~nm}\right), N_{I I}\left(5<D_{p}<1500 \mathrm{~nm}\right), \Delta N$ $\left(5<D_{p}<10 \mathrm{~nm}\right)$, and $\mathrm{SO}_{2}$.

Taking $\Delta N$ as an indicator for the presence of newly formed particles, the above profiles suggest, that between 06:26 and 06:53 UTC, new particle formation is taking place in the RL. Earlier measurements performed on 3 June 2002 in the RL (see Table 1) yielded $\Delta N_{\max }=0,200$, and $500 \mathrm{~cm}^{-3}$ at 05:04, 05:28 and 06:15 UTC, respectively. This indicates growth of newly formed particles into the detectable size range at a rate larger than the one estimated above. Below the inversion, the presence of small particle is most likely due to direct traffic emissions as ground-based NO and particle size distribution observations (see Fig. 12) suggest.

Figure 15 shows vertical profiles about $2 \mathrm{~h}$ later compared to the profiles depicted in Fig. 14. The profiles were measured during an ascent from ground to $610 \mathrm{~m}$. The inversion in $200 \mathrm{~m}$ had disappeared and $T$ shows a near-adiabatic lapse rate of $-0.9 \mathrm{~K}(100 \mathrm{~m})^{-1}$ over the complete altitude range. The profile of $a$ features some fluctuations over the complete profile but a sharp decrease in $550 \mathrm{~m}$, i.e., in the same height where a small increase of $T$ can be observed. In $350 \mathrm{~m}, a$ has a local maximum which corresponds with a change of the wind direction from south-east to north-east and an increased $U$. The particle concentrations show high values from the ground up to $550 \mathrm{~m}$. In this range $\Delta N$ varies between 1000 and $5000 \mathrm{~cm}^{-3}$ and $N_{I I}$ between 2000 and $12000 \mathrm{~cm}^{-3}$, respectively. Above $550 \mathrm{~m} \Delta N$ decreases rapidly to zero and $N_{I I} \approx N_{I}$ to about $1800 \mathrm{~cm}^{-3}$. The $\mathrm{SO}_{2}$-profile is nearly height independent with values around $0.3 \mathrm{ppb}$.

After these vertical profiles were taken, the balloon was fixed at $600 \mathrm{~m}$ again. The corresponding time series (Fig. 16), started about $10 \mathrm{~min}$ after the maximum height of the profiles shown in Fig. 15 was reached. The time series 


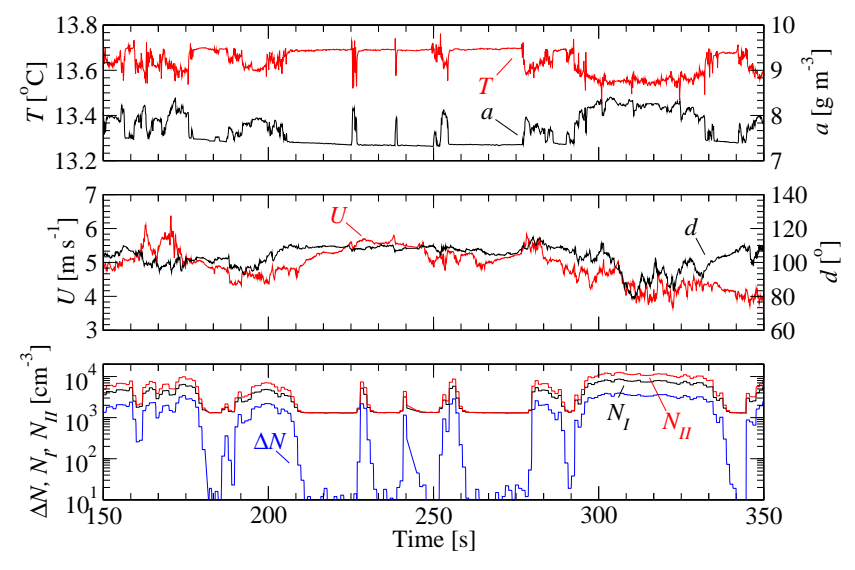

Fig. 16. Time series of temperature $T$, absolute humidity $a$, horizontal wind speed $U$, wind direction $d$, particle number concentration $N_{I}\left(10<D_{p}<1500 \mathrm{~nm}\right), N_{I I}\left(5<D_{p}<1500 \mathrm{~nm}\right)$, and $\Delta N$ $\left(5<D_{p}<10 \mathrm{~nm}\right)$ at constant level in $600 \mathrm{~m}$ (08:59-09:05 UTC).

of $T$ and $a$ but also $U$ and $d$ show very similar structure, periods with high fluctuations are interrupted by periods with nearly no structure. The same intermittent behavior is seen in the particle number concentrations. Most significant is $\Delta N$ which shows variations of several orders of magnitude with maximum values of 4000 to $5000 \mathrm{~cm}^{-3}$. The total concentration $N_{I I}$ varies between $1300 \mathrm{~cm}^{-3}$, which seems to be the background concentration (cf. also Fig. 13), and maximum values of up to $12000 \mathrm{~cm}^{-3}$ between $t=300$ and $340 \mathrm{~s}$. This behavior can be explained with up-drafts which temporarily penetrate into the RL. Therefore, sometimes ACTOS is inside of such an up-draft with highly increased turbulence and a significant number of newly formed particles and sometimes ACTOS is inside the RL where the turbulence is much weaker and $\Delta N$ is close to zero, i.e., no newly formed particles are detected.

This all together indicates, that at this stage, the ML has a height of about $550 \mathrm{~m}$. Taking again $\Delta N$ as an indicator for the presence of newly formed particles, the above profiles suggest, that between 08:43 and 09:05 UTC, new particle formation is taking place in the entire ML while inside the RL no newly formed particles were observed.

Summarizing the results of the ground-based and balloonborne measurements it can be stated that:

- New particle formation was observed inside the RL before the break-up of the nocturnal inversion.

- The particles newly formed in the RL grew up and were mixed down during the break-up process of the nocturnal inversion.

- No new particle formation was observed after the breakup of the nocturnal inversion in the RL.

- During and after the break-up of the nocturnal inversion new particle formation was observed in the ML.
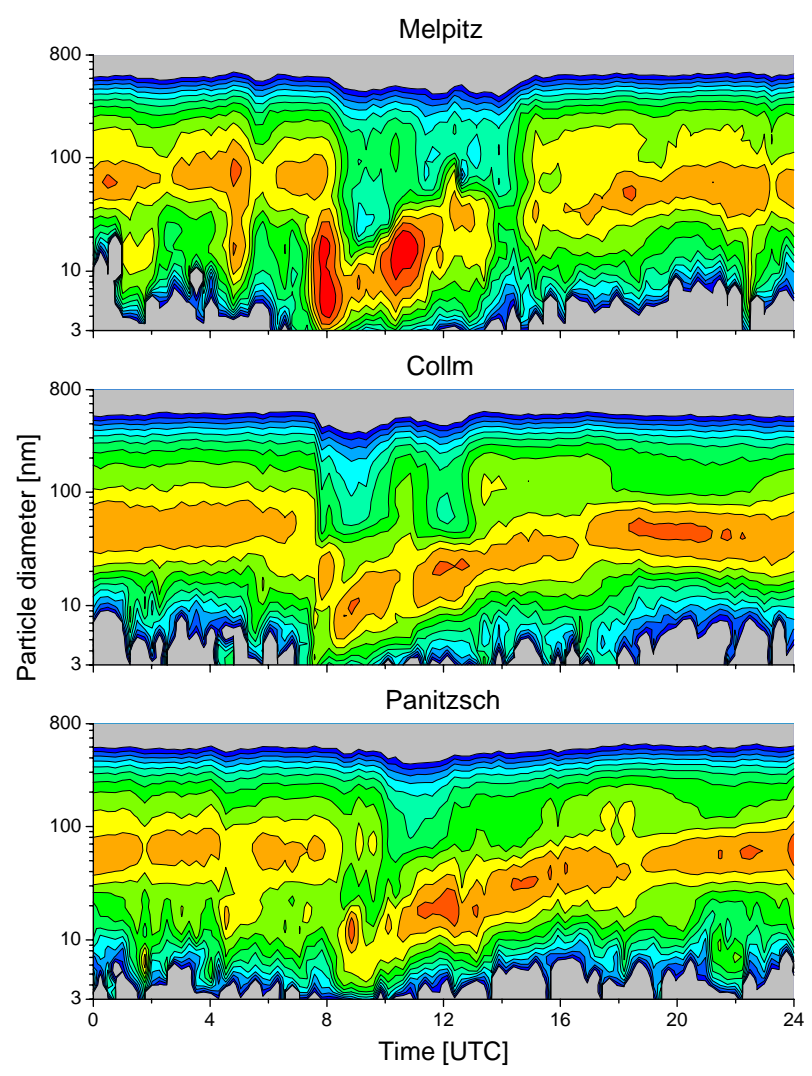

Fig. 17. Diurnal variation of number size distributions normalized by the total number concentration in Melpitz, Collm, and Panitzsch on 3 June 2002. Red colors indicates relative high concentrations, whereas blue indicates relative low concentrations.

Consequently, on 3 June 2002, two different new particle formation events, one inside the RL before and the second in the ML during and after the break-up of the nocturnal inversion were observed. The second event supports the hypothesis of Nilsson et al. (2001) who suggest a correlation between the onset of nucleation and the onset of turbulence. However, the new particle formation event observed in the RL suggests an addition to hypothesis 3 in Nilsson et al. (2001), i.e., the possibility that particles newly formed in the RL may grow into a dectable size range inside the RL.

\section{Comparison of particle size distributions at Melpitz, Collm, Panitzsch sites}

Figure 17 shows the diurnal variation of the normalized number size distributions for the three ground-based measurement sites on June 3, 2002. Each number size distribution measured by the TDMPS-systems was divided by the total number concentration from 3 to $800 \mathrm{~nm}$ to emphasize the location, i.e., the particle diameter, of the size distribution local maxima independent of the total number concentration. The observations at the Melpitz and Collm sites show a rapid 
increase in number concentration of particles with diameters between 3 and $20 \mathrm{~nm}$ and the particle size distributions feature local maxima at approximately 5 and $15 \mathrm{~nm}$. At the Panitzsch site, however, below $20 \mathrm{~nm}$, only one local maximum occurs which is located around $15 \mathrm{~nm}$. Compared to the Melpitz and Collm sites, the occurrence of this maximum is delayed by approximately half an hour in accordance with the delayed break-up of the nocturnal inversion layer as detected by the LIDAR-system at the Ift site about $10 \mathrm{~km}$ away. At the Panitzsch site, no local maximum at $5 \mathrm{~nm}$ was observed. This suggests that at the this site, new particle formation is significantly weaker throughout the evolution process of the PBL.

Considering the distances between the three sites, it is concluded that new particle formation is not a local phenomenon but its magnitude may vary locally to a significant extend.

\section{Summary and Outlook}

In this work, first results from the SATURN experiment have been presented. During the experiment, vertical soundings of meteorological parameters and particle number concentrations were carried out utilizing a balloon-borne measurement platform. In addition, ground-based measurements of particle number size distributions and gaseous precursor concentrations took place at the balloon site. At two additional locations (distance to the balloon site about $40 \mathrm{~km}$ ), particle number size distributions were measured. The vertical structure and the development of the PBL were observed utilizing a SODAR (at the ballon site) and a LIDAR system (distance about $50 \mathrm{~km}$ to the balloon site).

The SATURN experiment took place from 27 May to 14 June 2002. During this time period new-particle formation events were observed on 8 days. This paper focused on observations conducted on 3 June 2002 which was a typical clear-sky day. During night, a nocturnal inversion layer up to $200 \mathrm{~m}$ had developed below the overlaying RL. At around 07:00 UTC the inversion broke up and extensive vertical mixing increased the height of the ML up to about $1400 \mathrm{~m}$ in the afternoon. From the ground-based observations at the Melpitz site it was concluded that on 3 June 2002, new particle formation was induced by the break-up of the nocturnal inversion and proceeded throughout the evolution process of the PBL. The occurrence of a second local size distribution maximum in the particle size range below $20 \mathrm{~nm}$ was explained by the mixing down of particles that were newly formed and grew up to larger sizes inside the RL before the break-up of the nocturnal inversion. This hypothesis was supported by balloon-borne observations performed before the break-up of the nocturnal inversion. Balloon-borne observations carried out after the break-up of the nocturnal inversion indicated that new particle formation was taking place in the entire ML while inside the RL no newly formed particles were observed. Comparing the particle size distri- butions observed at the three measurement sites, it was found that at two sites the evolution of the particle size distributions was similar. At the third site, in the particle size range below $20 \mathrm{~nm}$, only particles supposedly formed in the RL and almost no newly formed particles were observed.

Summarizing the presented results it can be stated that new particle formation a) may take place inside the RL before the break-up of the nocturnal inversion, b) may be induced by the break-up of the nocturnal inversion, c) may proceed during the evolution of the PBL, d) is not a local phenomena but d) may vary locally to a significant extend. Consequently, there seems to be no definite answer regarding the question whether observed newly formed particles nucleated near the ground or were mixed down from above. Data collected during the SATURN experiment suggest that both scenarios, i.e., a) situations where particles were formed in higher-up regions such as the RL (this paper) and in the vicinity of an inversion layer (Siebert et al., 2003b,c) and b) new particle formation in the ML near ground (this paper), may take place. I.e., under different PBL conditions different types of mechnisms as discussed in Nilsson et al. (2001) are possible.

Further detailed analysis of the SATURN data will be necessary to give a deeper insight in the process and location of new particle formation. For example, the estimation of the vertical turbulent particle flux as calculated from the balloon data should give an indication of the source of the newly formed particles.

Acknowledgements. The authors acknowledge, the german Bundeswehr for their kind provision of the tethered balloon MAPS-Y, G. Sanftleben and his co-workers from the Bundeswehr Technical Centre for Ships and Naval Weapons for their excellent and very cooperative operation of the tethered balloon, J. Strüning and coworkers from the Office of Military Geophysics for his support, the Ift department heads (J. Heintzenberg, H. Herrmann, E. Renner) for making available the necessary financial resources, T. Conrath, A Grüner, J. Hanss and the staff of the Collm observatory for supplying the needed and important technical support and A. Nowak for providing his meteorological expertise. Without all these contributors, the SATURN experiment would have been impossible!

\section{References}

Banse, D. F., Esfeld, K., Hermann, M., Sierau, B., and Wiedensohler, A.: Particle counting efficiency of the TSI CPC 3762 for different operating parameters, J. Aerosol Sci., 32, 157-161, 2001.

Beyrich, F. and Weill, A.: Some aspects of determination the stable boundary layer depth from SODAR data, Boundary-Layer Meteorol., 63, 97-116, 1993.

Bigg, E. K.: A mechanism for the formation of new particles in the atmosphere, Atm. Res., 43, 129-137, 1997.

Birmili, W., Stratmann, F., and Wiedensohler, A.: Design of a DMA-based Size Spectrometer for large particle size range and stable operation, J. Aerosol Sci., 30, (4), 549-554, 1999. 
Birmili, W. and Wiedensohler, A.: New particle formation in the continental boundary layer: Meteorological and gas phase parameter influence, Geophys. Res. Lett., 27, 3325-3328, 2000.

Bösenberg, J., Ansmann, A., Baldasano, J. M., Balis, D., Böckmann, C., Calpini, B.,, Chaikovski, A., Flamant, P., Hagard, A., Mitev, V., Papayannis, A., Pelon, J., Resendes, D., Schneider, J., Spinelli, N., Trickl, T., Vaughan, G., Visconti, G., and Wiegner, M.: EARLINET: A European Aerosol Research Lidar Network, in: Advances in Laser Remote Sensing, Dabas, A., Loth, C., and Pelon, J. (Eds), Ecole Polytechnique, 91128 Palaiseau, France, 155-158, 2001.

Buzorius, G., Rannik, U., Mäkelä, J. M., Vesala, T., and Kulmala, M.: Vertical aerosol particle fluxes measured by eddy covariance technique using condensational particle counter, J. Aerosol Sci., 29, 157-171, 1998.

Charlson, R. J. and Heintzenberg, J. (Eds), Aerosol Forcing of Climate, John Wiley \& Sons, Chichester, 1995.

Clarke, A. D.: Atmospheric nuclei in the remote free troposphere, J. Atmos. Chem., 14, 479-488, 1992.

Dockery, D. W. and Pope, C. A.: Acute respiratory effects of particulate air pollution, Annu. Rev. 5 Public. Health, 15, 107-132, 1994.

Easter, R. C. and Peters, L. K.: Binary homogeneous nucleation: Temperature and relative humidity fluctuations, nonlinearity, and aspects of new particle formation in the atmosphere, J. Appl. Met., 33, 775-784, 1994.

ECMWF: User guide to ECMWF products 2.1, Meteorological Bulletin M3.2, ECMWF, Reading, UK, 1995.

Haman, K., Malinowski, S. P., Struś, B. D., Busen, R., Stefko, A., and Siebert, H.: A family of ultrafast aircraft thermometers for warm and supercooled clouds and various types of aircraft, Preprints $13^{\text {th }}$ International Conference on Clouds and Precipitation, Reno, NV, USA (14-18 August 2000), 2000.

Hegg, D. A., Radke, L., and Hobbs, P. V.: Particle production associated with marine clouds, J. Geophys. Res., 95, 13 917-13 926, 1990.

Hellmuth, O. and Helmert, J.: Parameterization of turbulenceenhanced nucleation in large scale models: Conceptual study, Air Pollution Modeling and Its Application, XV, Borrego and Schayes (Eds), Kluwer Academic/Plenum Publishers, New York, 295-304, 2002.

Hoppel, W. A., Frick, G. M., Fitzgerald, J. W., and Larson, R. E.: Marine boundary layer measurements of new particle formation and the effects nonprecipitating clouds clouds have on the aerosol size distribution, J. Geophys. Res., 99, 14 443-14 459, 1994.

Keil, A. and Wendisch, M.: Bursts of Aitken mode and ultrafine particles observed at the top of continental boundary layer clouds, J. Aerosol Sci., 32, 649-660, 2001.

Lehtinen, K. E. J. and Kulmala, M.: A model for particle formation and growth in the atmosphere with molecular resolution in size, Atmos. Chem.Phys., 3, 251-257, 2003

Mäkelä, J. M., Aalto, P., Jokinen, V., Pohja, T., Nissinen, A., Palmroth, S., Markkanen, T., Seitsonen, K., Lihavainen, H., and Kulmala, M.: Observations of ultrafine aerosol particle formation and growth in boreal forest, Geophys. Res. Lett., 24, 1219-1222, 1997.

Mattis, I., Ansmann, A., Althausen, D., Jaenisch, V., Wandinger, U., Müller, D., Arshinov, Y. F., Bobrovnikov, S. M., and Serikov, I. B.: Relative-humidity profiling in the troposphere with a Raman lidar, Appl. Opt., 41, 6451-6462, 2002.

McMurry, P. H., Woo, K. S., Weber, R. J., Chen, D.-R., and Pui, D. Y. H.: Size distributions of 3-10 nm atmospheric particles: implications for nucleation mechanisms, Phil. Trans. R. Soc. Lond. A, 358, 2625-2642, 2000.

Neff, W. D. and Coulter, R. L.: Acoustic Remote Sensing, Probing the atmospheric boundary layer, Lenschow, D. H. (Ed), American Meteorological Society, Boston, USA, 239 p, 1986.

Nilsson, E. D. and Kulmala, M.: The potential for atmospheric mixing processes to enhance the binary nucleation rate, J. Geophys. Res., 103, 1381-1389, 1998.

Nilsson, E. D., Pirjola, L., and Kulmala, M.: The effect of atmospheric waves on aerosol nucleation and size distribution, J. Geophys. Res., 105, 19917-19926, 2000.

Nilsson, E. D., Rannik, Ü., Kulmala, M., Buzorius, G., and O'Dowd, C.: Effects of continental boundary layer evolution, convection, turbulence and entrainment, on aerosol formation, Tellus, 53B, 441-461, 2001.

O’Dowd, C., McFiggans, G., Creasey, D. J., Pirjola, L., Hoell, C., Smith, M. H., Allan, B. J., Plane, J. M. C., Heard, D. E., Lee, J. D., Pilling, M. J., and Kulmala, M.: On the photochemical production of new particles in the coastal boundary layer, Geophys. Res. Lett., 26, 1707-1710, 1999.

Pirjola, L., Laaksonen, A., Aalto, P., and Kulmala, M.: Sulfate aerosol formation in the Arctic boundary layer, J. Geophys. Res., 103, 8309-8321, 1998.

Schröder, F. and Ström, J.: Aircraft measurements of submicrometer aerosol particles $(>7 \mathrm{~nm})$ in the midlatitude free troposphere and tropopause region, Atmos. Res., 44, 333-356, 1997.

Siebert, H. and Muschinski, A.: Relevance of a Tuning-Fork Effect for Temperature Measurements with the Gill Solent HS Ultrasonic Anemometer-Thermometer, J. Atmos. Oceanic Tech., 18, 1367-1376, 2001.

Siebert, H.: Tethered-balloon borne turbulence measurements in the cloudy boundary layer, Ph.D. thesis, University of Leipzig, Germany, 2001.

Siebert, H., Wendisch, M., Conrath, T., Teichmann, U., and Heintzenberg, J.: A new tethered balloon-borne payload for finescale observations in the cloudy boundary layer, Boundary-Layer Meteorol., 106, 461-482, $2003 \mathrm{a}$.

Siebert, H., Stratmann, F., and Wehner, B. : Observations of ultrafine particle bursts in the inversion layer and its relation to ground-based measurements: a case study, in preparation for Geophys. Res. Lett., 2003b.

Siebert, H., Stratmann, F., and Wehner, B.: New particle formation observed during the SATURN experiment at inversion layers a case study, J. Aerosol Sci., Abstracts of EAC, Madrid 2003, $2003 c$.

Slanina, J., de Wild, P. J., and Wyers, G. P.: The application of denuder systems to the analysis of atmospheric components in: Gaseous pollutants characterization and cycling, Nriagu, J. O. (Ed), Advances in Environmental Science and Technology, Vol. 24., John Wiley and Sons Ltd, New York, USA 1992.

Spindler, G., Mölders, N., Hanss, J., Beier, N., and Kramm, G.: Determining the dry deposition of $\mathrm{SO}_{2}, \mathrm{O}_{3}, \mathrm{NO}$, and $\mathrm{NO}_{2}$ at the SANA core station Melpitz, Meteorol. Zeitschift, N.F. 5, 205220, 1996.

Spindler, G., Teichmann, U., and Sutton, M. A.: Ammonia dry deposition over grassland - micrometeorological flux-gradient 
measurements and bidirectional flux calculation using an inferential model, Q. J. R. Meteorol. Soc., 127, 795-814, 2001.

Stohl, A., Wotawa, G., Seibert, P., and Kromp-Kolb, H.: Interpolation errors in wind fields as a function of spatial and temporal resolution and their impact on different types of kinematic trajectories, J. Appl. Meteor., 34, 2149-2165, 1995.

Stull, R. B.: An introduction to boundary layer meteorology, Kluwer Academic Publishers, Dordrecht, The Netherlands, 666 p, 1988.

Uhrner, U., Birmili, W., Stratmann, F., Wilck, C., Ackermann, I. J., and Berresheim, H.: Particle Formation at a Continental Background Site: Comparison of Model Results with Observations., Atmos. Chem. Phys., 3, 347-359, 2003.

Weber, R. J., Marti, J. J., McMurry, P. H., Eisele, F. L., Tanner, D. J., and Jefferson, A.: Measurements of new particle formation and ultrafine particle growth rates at a clean continental site, J. Geophys. Res., 102, 4375-4385, 1997.
Weber, R. J., McMurry, P. H., Mauldin, R. L., Tanner, D. J., Eisele, F. L., Clarke, A. D., and Kapustin, V. N.: New particle formation in the remote troposphere: A comparison of observations at various sites, Geophys. Res. Lett., 26, 307-310, 1999.

Wiedensohler, A., Covert, D. S., Swietlicki, E., Aalto, P., Heintzenberg, J., and Leck, C.: Occurrence of an ultrafine particle mode less than $20 \mathrm{~nm}$ in diameter in the marine boundary layer rence 20 during Arctic summer and autumn, Tellus, 48B, 213-222, 1996.

Wiedensohler, A., Hansson, H.-C., Orsini, D., Wendisch, M., Wagner, F., Bower, K. N., Choularton, T. W., Wells, M., Parkin, M., Acker, A., Wieprecht, W., Fachini, M. C., Lind, J. A., Fuzzi, S., Arends, B. G. and Kulmala, M.: Night-time formation and occurrence of new particles associated with orographic clouds, Atmos. Environ. 31, 2545-2559, 1997.

Wyers, G. P., Otjes, R. P., and Slanina, J.: A continuous-flow denuder for the measurement of ambient concentrations and surface-excange of ammonia, Atmos. Environ., 27A, 2085-2090, 1993. 